\title{
Population structure of Mytilus edulis in the intertidal zone in a sub-Arctic fjord, SW Greenland
}

\author{
Martin E. Blicher ${ }^{1, *}$, Mikael K. Sejr ${ }^{2}$, Signe Høgslund ${ }^{3}$ \\ ${ }^{1}$ Greenland Climate Research Centre, Greenland Institute of Natural Resources, Kivioq 2, Box 570, 3900 Nuuk, Greenland \\ ${ }^{2}$ Arctic Research Centre, Institute for Bioscience, Aarhus University, C.F. Møllers Allé 8, 8000 Aarhus C, Denmark \\ ${ }^{3}$ Department of Marine Ecology, Institute for Bioscience, Aarhus University, Vejlsøvej 25, 8600 Silkeborg, Denmark
}

\begin{abstract}
The blue mussel Mytilus edulis is widely distributed and acknowledged for its ecological importance in the intertidal zone in northern temperate areas. However, detailed studies of the structure and dynamics of intertidal $M$. edulis populations are lacking in its northern distribution area. This study provides baseline information on the population structure of $M$. edulis in the mid-intertidal zone of the sub-arctic Godthåbsfjord in West Greenland $\left(64^{\circ} \mathrm{N}\right)$. Abundance was very patchy (average 18.6 ind. $0.049 \mathrm{~m}^{-2}$; range 0 to 312) and concentrated around crevices, boulders and macroalgae beds. Average biomass was $7.78 \mathrm{~g}$ wet mass $0.049 \mathrm{~m}^{-2}$. Young specimens $<3$ yr old (or $<15 \mathrm{~mm}$ shell length) made up $82 \%$ of the population. Maximum age was estimated at $19 \mathrm{yr}$. The age structure suggested that the annual instantaneous mortality rate, $Z$, gradually decreased with age from 0.82 to 0.12 . Growth functions obtained from size-at-age data showed significant differences between sampling sites in the Godthåbsfjord, overall covering much of the geographical variation found in the North Atlantic. The absence of invertebrate predators in the intertidal in this sub-Arctic habitat suggests that physical drivers are important for structuring the $M$. edulis community. Winter temperatures below $-15^{\circ} \mathrm{C}$ combined with ice scouring are suggested to be the key drivers. Crevices, boulders and macroalgae beds are important refuges during detrimental extreme events but also provide variable growth conditions.
\end{abstract}

KEY WORDS: Bivalve $\cdot$ Growth $\cdot$ Mortality $\cdot$ Ice scouring $\cdot$ Climate $\cdot$ Temperature $\cdot$ Epifauna Predator regulation $\cdot$ Environmental drivers

\section{INTRODUCTION}

Increasing temperatures in the Arctic may challenge the temperature tolerance of Arctic species and cause a poleward contraction of their distribution (ACIA 2004). Similar general predictions suggest that boreal species may increase their northern range. However, well-documented examples of distributional changes are scarce for the Arctic marine ecosystem due to lack of consistent time series and baseline data (Wassmann et al. 2011). The rocky intertidal zone is among the best-studied marine habitats and has long served as a model for investigating the effects of climate on species distributions and ecosystems. Some of the best-documented changes in response to climate have occurred on rocky shores in temperate regions (Sagarin et al. 1999, Mieszkowska et al. 2006, Herbert et al. 2009).

The blue mussel Mytilus edulis is a common species in the intertidal zone in temperate and northern temperate areas in the North Atlantic. Due to its wide distribution and ecological importance, it has been intensely studied for decades. It is considered to be competitively superior especially on steep, waveexposed sites and can form dense beds which dominate the mid-intertidal zone (Seed \& Suchanek 1992). Such mussel beds are highly productive, are a primary food source for birds, fish and invertebrates, and provide habitat and refuge for numerous organisms, thus establishing a unique community of algae and animals (Seed \& Suchanek 1992). Detailed studies from various locations in temperate areas suggest 
that the distribution of $M$. edulis in the intertidal zone can be influenced directly or indirectly by an array of different biological and physical factors, such as: (1) predation (primarily by whelk, starfish and crab), (2) inter-specific competition for space (barnacle, fucoid algae or other Mytilus species), and (3) air temperature, desiccation, wave action, salinity and substrate heterogeneity, which may in turn affect the level of predation or competition (e.g. Seed 1969, Menge 1976, Suchanek 1978, Archambault \& Bourget 1996, Bertness et al. 1999, Menge 2000, Westerbom et al. 2002, Jones et al. 2010). However, temperature is considered to be the primary factor influencing large-scale distributional limits (Jones et al. 2010). It is estimated that the southern range limit has shifted $350 \mathrm{~km}$ northward along the American east coast (Jones et al. 2009) due to warming. Similarly, the northern distributional limit is presumably determined by minimum air temperature in winter. Lower thermal limits (median lethal temperature, $\mathrm{LT}_{50}$ ) have been estimated to be $-12.5^{\circ} \mathrm{C}$ for small $(<1.5 \mathrm{~cm})$ to $-17.5^{\circ} \mathrm{C}$ for large $(>3 \mathrm{~cm})$ specimens (Bourget 1983). M. edulis is known to inhabit intertidal, and especially subtidal habitats in sub-arctic and Arctic regions of Norway, Russia, Canada and Greenland (Theisen 1973, Wallace 1980, Thompson 1984, Sukhotin et al. 2007). The northernmost observations are sporadic sub tidal occurrences at $77^{\circ} \mathrm{N}$ in Greenland and $78^{\circ} \mathrm{N}$ in Svalbard (Theisen 1973, Berge et al. 2005). There is a range overlap between $M$. edulis and the very similar congener $M$. trossulus throughout the North Atlantic. However, genetic studies of blue mussels in Greenland waters have not identified any species other than $M$. edulis (Wanamaker et al. 2007, Versteegh et al. 2012).

Detailed knowledge of the structure and dynamics of intertidal Mytilus edulis populations within the northern distribution area is lacking. Population structures may differ from other geographical areas because of the harsher environment (i.e. lower minimum air and water temperature and potential ice scouring) and presumed absence of invertebrate predators in the intertidal zone (Bergeron \& Bourget 1986). Thus, M. edulis may suffer to some extent in the harsh environment but at the same time benefit from low predation pressure. The outcome of these opposing controls is not easily predicted. The aim of this study is to provide baseline information on the population structure of $M$. edulis in the intertidal zone of a sub-arctic fjord in West Greenland. We hypothesized that the negative effect of the harsh environmental conditions would be strong enough to cancel out any positive effect of predator absence. If environmental harshness is not too detrimental, we should expect to observe higher mussel abundances and higher individual ages compared to sites with intense predation.

\section{MATERIALS AND METHODS}

\section{Study area}

The Godthåbsfjord system is situated in the subArctic, SW Greenland $\left(64^{\circ} \mathrm{N}, 51^{\circ} \mathrm{W}\right)$ (Fig. 1). The fjord system is complex and made up of a number of fjord branches. The inner part of the main fjord is in contact with 3 tidal outlet glaciers. The distance from the mouth to the head covers $187 \mathrm{~km}$. The shoreline has an estimated total length of $1272 \mathrm{~km}$, consisting almost exclusively of rocky coast or talus (Mosbech et al. 2000, Mortensen et al. 2011). The tidal amplitude varies from 1 to $5 \mathrm{~m}$ depending on moon phase. In the outer part of the fjord, sea surface temperature reaches a minimum of $<0^{\circ} \mathrm{C}$ during winter and a maximum of 5 to $8^{\circ} \mathrm{C}$ in late summer, and surface salinity varies seasonally from 20 to 34 psu (Arendt et al. 2013). Minimum and maximum air temperatures show substantial variation from year to year and from the entrance to the mouth of the fjord. Typical winter minimum air temperature is in the range of -15 to $-25^{\circ} \mathrm{C}$ and summer maximum is at ca. $20^{\circ} \mathrm{C}$ in the entrance; the temperature amplitude is even greater in the fjord mouth, where winter minimum temperature is lower and maximum summer temperature higher (A. Asiaq unpubl.; see Table 5).

\section{Sampling}

Mytilus edulis were collected at 15 stations in the Godthåbsfjord system during 1 wk in early June 2011 (Fig. 1, Table 1). All samplings were conducted during low tide in the mid-intertidal zone, which was located by using a biological indicator (i.e. a vertical distance of $1.6 \mathrm{~m}$ below the highest observed macroalgae Fucus sp.). Each station was represented by 10 replicate samples, each covering a surface area of $0.049 \mathrm{~m}^{2}$, placed at a fixed distance along a $25 \mathrm{~m}$ transect line parallel to the coastline.

At some of the stations, a qualitative sampling of rare large mussels was conducted in the midintertidal zone. These were included in an analysis of growth patterns. All specimens were frozen $\left(-18^{\circ} \mathrm{C}\right)$ shortly after collection and kept frozen until further analysis. At each station the overall physical (slope, 
rugosity) and biological (algae cover) characteristics were determined by visual examination. Moreover, the potential exposure to ice scouring was specified based on the proximity to glaciers and local knowledge about ice conditions. Presence/absence of po- tential invertebrate predators of Mytilus edulis was registered. Finally, a wave exposure index was calculated as a proxy for wave exposure for each station. Based on a digital map of the Godthåbsfjord $(25 \times$ $25 \mathrm{~m}$ grid resolution) the flow distance to nearest

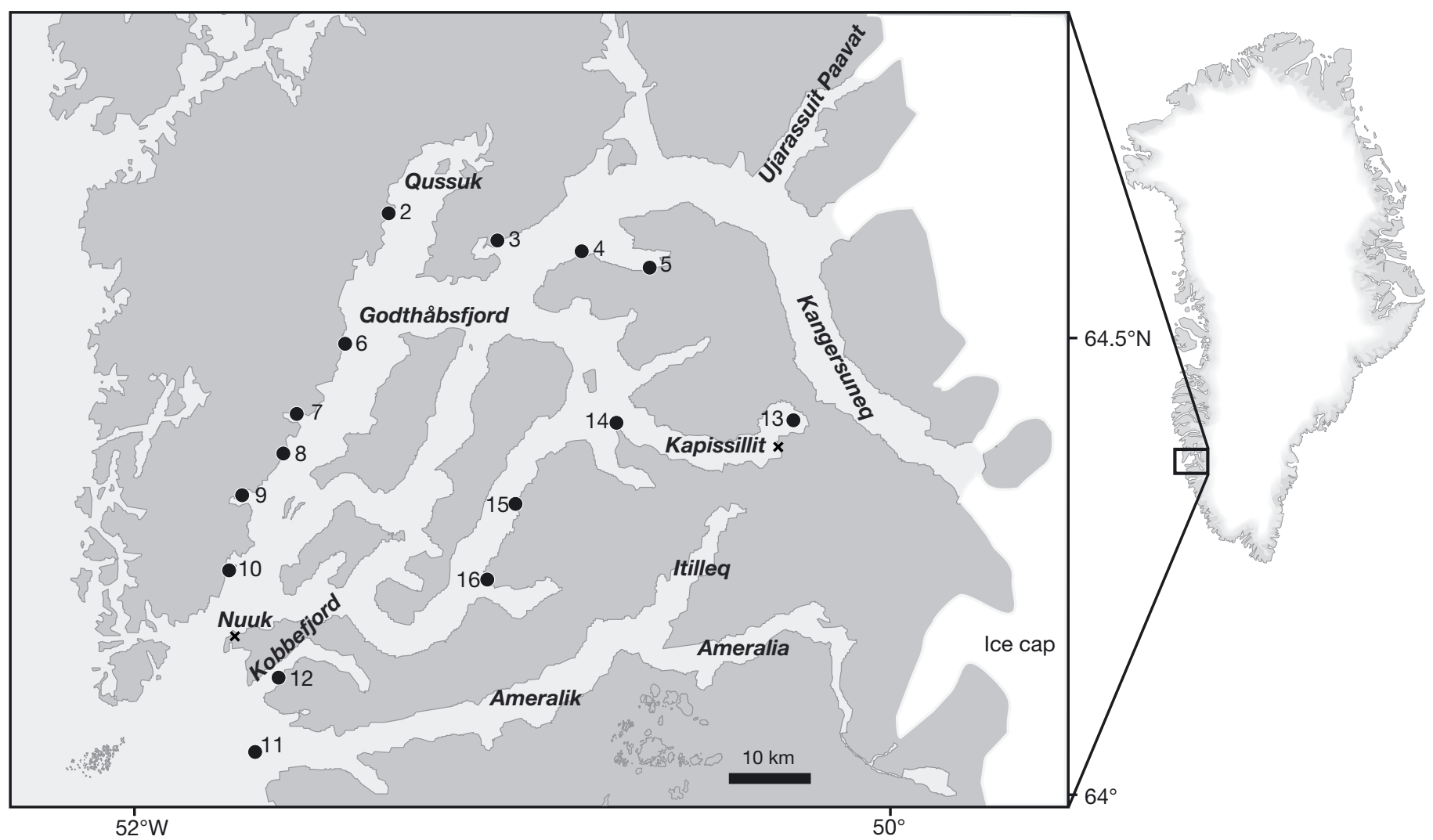

Fig. 1. Locations of Mytilus edulis collection (•) and climate stations (x) in the Godthåbsfjord, SW Greenland

Table 1. Characteristics of the 15 sites in the Godthåbsfjord system, Greenland, sampled in early June 2011

\begin{tabular}{|c|c|c|c|c|c|c|c|}
\hline Stn no. & N latitude & W longitude & $\begin{array}{c}\text { Algae } \\
\text { cover }(\%)\end{array}$ & $\begin{array}{l}\text { Slope } \\
\left({ }^{\circ}\right)\end{array}$ & Rugosity & $\begin{array}{c}\text { Influence by } \\
\text { drift ice (glacial) }\end{array}$ & $\begin{array}{l}\text { Wave exposure } \\
\text { index }\left(\mathrm{m}^{2} \mathrm{~s}^{-1}\right)\end{array}$ \\
\hline 2 & $64^{\circ} 41.116^{\prime}$ & $51^{\circ} 18.512^{\prime}$ & 80 & 10 & Low & Medium & 1436 \\
\hline 3 & $64^{\circ} 38.679^{\prime}$ & $51^{\circ} 01.114^{\prime}$ & 25 & 10 & Medium & Heavy & 1024 \\
\hline 4 & $64^{\circ} 38.354^{\prime}$ & $50^{\circ} 47.766^{\prime}$ & 0 & 20 & Low & Heavy & 2917 \\
\hline 5 & $64^{\circ} 37.682^{\prime}$ & $50^{\circ} 35.168^{\prime}$ & 20 & 10 & Low & Heavy & 1179 \\
\hline 6 & $64^{\circ} 31.664^{\prime}$ & $51^{\circ} 25.991^{\prime}$ & 10 & 5 & Low & Medium & 5335 \\
\hline 7 & $64^{\circ} 26.854^{\prime}$ & $51^{\circ} 34.051^{\prime}$ & 75 & 20 & Medium & Medium $^{\mathrm{a}}$ & 638 \\
\hline 8 & $64^{\circ} 23.965^{\prime}$ & $51^{\circ} 36.482^{\prime}$ & 80 & 20 & Low & Medium & 34481 \\
\hline 9 & $64^{\circ} 20.790^{\prime}$ & $51^{\circ} 42.546^{\prime}$ & 85 & 45 & Medium & Medium $^{a}$ & 1419 \\
\hline 10 & $64^{\circ} 15.812^{\prime}$ & $51^{\circ} 43.908^{\prime}$ & 5 & 10 & Low & Medium & 18969 \\
\hline 11 & $64^{\circ} 03.150^{\prime}$ & $51^{\circ} 37.304^{\prime}$ & 20 & 10 & High & Medium & 2940 \\
\hline 12 & $64^{\circ} 07.869^{\prime}$ & $51^{\circ} 37.473^{\prime}$ & 100 & 15 & Low & Low & 2014 \\
\hline 13 & $64^{\circ} 26.648^{\prime}$ & $50^{\circ} 13.397^{\prime}$ & 60 & 25 & Medium & Low $^{a}$ & 2256 \\
\hline 14 & $64^{\circ} 26.715^{\prime}$ & $50^{\circ} 42.833^{\prime}$ & 35 & 20 & Low & Medium & 2989 \\
\hline 15 & $64^{\circ} 21.187^{\prime}$ & $50^{\circ} 58.450^{\prime}$ & 80 & 10 & Medium & Low & 7091 \\
\hline 16 & $64^{\circ} 16.065^{\prime}$ & $51^{\circ} 03.380^{\prime}$ & 30 & 5 & High & Low & 5314 \\
\hline
\end{tabular}


Table 2. Hourly wind data from Godthåbsfjord, Greenland, between 2005 and 2010 (obtained from climate station Nuuk 522). The average wind speed (for wind speeds $>10 \mathrm{~m} \mathrm{~s}^{-1}$ ) and relative distribution among the 8 main directions were used to calculate the wind impact factor

\begin{tabular}{|lccccc|}
\hline Octant & Counts & $\begin{array}{c}\text { Max speed } \\
\left(\mathrm{m} \mathrm{s}^{-1}\right)\end{array}$ & $\begin{array}{c}\text { Average speed } \\
\left(\mathrm{m} \mathrm{s}^{-1}\right)\end{array}$ & Frequency & $\begin{array}{c}\text { Impact } \\
\text { factor }\end{array}$ \\
\hline $\mathrm{N}$ & 686 & 21.45 & 12.2392 & 0.01506 & 0.1844 \\
$\mathrm{NE}$ & 836 & 21.74 & 11.6937 & 0.01836 & 0.2147 \\
$\mathrm{E}$ & 173 & 25.28 & 13.3066 & 0.00380 & 0.0506 \\
$\mathrm{SE}$ & 480 & 25.84 & 13.7027 & 0.01054 & 0.1444 \\
$\mathrm{~S}$ & 3911 & 33.82 & 14.8006 & 0.08588 & 1.2711 \\
$\mathrm{SW}$ & 276 & 24.8 & 13.0159 & 0.00606 & 0.0789 \\
$\mathrm{~W}$ & 39 & 16.29 & 11.4544 & 0.00086 & 0.0098 \\
$\mathrm{NW}$ & 102 & 15.12 & 11.7172 & 0.00224 & 0.0262 \\
\hline
\end{tabular}

shoreline was calculated in 8 directions $(\mathrm{N}, \mathrm{S}, \mathrm{E}, \mathrm{W}$, NE, SE, SW and NW) from each of our sampling stations. The distance in pixels to the nearest coastline in the 8 directions was then multiplied by the pixel size $(25 \mathrm{~m})$ in the 4 main directions $(\mathrm{N}, \mathrm{S}, \mathrm{E}$, and $\mathrm{W})$ and by $35 \mathrm{~m}$ in the diagonal directions (NE, SE, SW and NW). The estimated distance to nearest shore in each of the 8 directions was then multiplied by the wind impact factor estimated from hourly data on wind speed and direction from a local climate station (Nuuk 522) from 2005-2010 (Table 2). Only wind speeds above $10 \mathrm{~m}$ $\mathrm{s}^{-1}$ were considered to be important for wave generation. The wind impact factor was calculated for each direction by: Wind impact factor $=$ Frequency $\times$ Average wind speed (>10 $\left.\mathrm{m} \mathrm{s}^{-1}\right)$.

To calculate the wave exposure index for each sampling station, the flow distance (in m) was multiplied by the wind impact factor $\left(\mathrm{m} \mathrm{s}^{-1}\right)$ in each of the 8 directions and summed.

\section{Population structure}

For each replicate sample the number of Mytilus edulis was counted. For each individual, shell length was measured to the nearest $0.01 \mathrm{~mm}$ using digital calipers, and wet mass (WM) was determined to the nearest $0.001 \mathrm{~g}$. A high-resolution digital photograph was taken of the smallest specimens (ca. $<3 \mathrm{~mm}$ ) from each replicate sample, and shell lengths were measured using the image processing software, ImageJ (rsb.info.nih.gov/ij/). Individual WM of these small individuals $(<0.005 \mathrm{~g})$ was estimated from a general size-mass relation based on the larger mussels in the samples, and validated by weighing subsamples. Descriptive statistics and statistical tests were performed using SAS 9.2 software (SAS Institute).
The number of winter growth checks was also counted on each shell. To evaluate the use of shell growth checks for age determination of Mytilus edulis in the Godthåbsfjord, we conducted a 1 yr tagging-recapture experiment. In late May 2010, 25 individuals with a known shell length were tagged with numbered Shellfish tags (Hallprint) attached near the shell margin with a cyanoacrylate adhesive (Ross et al. 2001). The tagged mussels were transferred to a culture sock (tubular mesh material) of ca. $25 \mathrm{~cm}$ length, which was tied to a rock anchor in the intertidal zone at a site in Kobbefjord (Fig. 1, near Stn 12). Mussels were recaptured in early June 2011 for examination of growth check formation.

Based on size-at-age data, we analysed the growth patterns of Mytilus edulis in the Godthåbsfjord. This analysis was based on maximum likelihood estimation. An initial model proposed that growth would follow a sigmoidal growth curve of the Richards family (Richards 1959, Sugden et al. 1981):

$S_{t}\left(S_{\infty}, m, t_{*}, T\right)=S_{\infty}\left[1-(1-m) \exp \left\{\frac{-\left(t-t_{*}\right)}{T m^{m /(1-m)}}\right\}\right]^{1 /(1-m)}$

where $S_{\infty}$ is the asymptotic shell length $(\mathrm{mm}), t$ is individual age (yr), $t_{*}$ is an age-at-growth inflexion, $T$ (yr) is the time needed to grow from zero to $S_{\infty}$ at maximum growth rate, and $m$ is a shape factor for Richards curves. An $m \rightarrow 0$ corresponds to von Bertalanffy growth, $m \rightarrow 1$ to Gompertz, and $m=2$ to single logistic. An error term was considered, such that:

$$
S_{t}=S_{t}\left(S_{\infty}, m_{1} t_{*}, T\right)+\varepsilon_{t}
$$

where $S_{t}$ is the actual shell length. $\varepsilon_{t}$ is assumed to be normally distributed with zero mean and a power relationship between its variance and the predicted shell length, $S_{t}\left(S_{\infty}, m, t_{*}, T\right)$ :

$$
\varepsilon_{t} \sim N\left\{0,\left[a S_{t}\left(S_{\infty}, m, t_{*}, T\right)^{b}\right]^{2}\right\}
$$

where $a$ and $b$ define the variance. This is a flexible expression of variance, which includes potential heteroscedasticity. Parameters were fitted by maximising the joint likelihood of the $\varepsilon_{t}$ values, $\operatorname{Ln}(L)$. An initial model fitted values of all 6 parameters to each of the 15 groups, and the model was reduced by constraining parameter values for different groups to be equal or to have specific values. Constraints were tested by likelihood-ratio tests, where the value $-2 \operatorname{Ln}\left(L_{0} / L_{1}\right)$ was tested as $\chi^{2}$ with degrees of freedom equal to the 
number of constraints. Akaike's Information Criterion, $\mathrm{AIC}=-2 \operatorname{Ln}(L)+2 K$ where $K$ is the number of parameters in the model, was also referred to in respect of choosing one model over another (Lebreton et al. 1992). The model fitting was done using Microsoft Excel Solver.

The age distribution was used to estimate average annual mortality rates in the fjord system, by applying a negative exponential mortality model to the data: $N_{t}=N_{0} \cdot \mathrm{e}^{-Z \cdot t}$, where $N_{0}$ is the initial number of mussels in an age class, $N_{t}$ is the number at age $t(\mathrm{yr})$, and $Z$ is the instantaneous mortality rate.

\section{RESULTS}

\section{Abundance and biomass}

The abundance of Mytilus edulis was very patchy. Highest concentrations were associated with crevices and boulders, sheltered locations, and the macroalgae Ascophyllum nodosum. Very few (and only mussels of small size) were found on smooth surfaces. At most stations abundance data could not be considered normally distributed as indicated by Kolmogorov-Smirnov tests $(\mathrm{p}<0.05)$. The result of a Kruskal-Wallis test was significant $\left(\chi^{2}=37.53, \mathrm{df}=\right.$ $14, \mathrm{p}<0.001)$; the mean ranks of individuals per sample (abundance) were significantly different among the 15 stations. The variation in abundance is illustrated in Fig. 2A and summarized in Table 3. Overall, minimum and maximum numbers of mussels per sample were 0 and 312 , respectively. The mean, median and mode values were 18.6, 1.0 and 0 ind. $0.049 \mathrm{~m}^{-2}$, respectively, reflecting a strongly rightskewed distribution. Nearly half of the samples $(\mathrm{n}=$ 71) had zero abundance of $M$. edulis, and only 32 out of 150 samples had abundances higher than the overall average of 18.6 ind. $0.049 \mathrm{~m}^{-2}$. Maximum abundance was found at Stn 2 with a mean (median) of 116.2 (84.5) ind. $0.049 \mathrm{~m}^{-2}$.

The biomass of Mytilus edulis varied accordingly within and between stations. The mean ranks of WM per sample were significantly different among the 15 stations (Kruskal-Wallis, $\chi^{2}=27.51, \mathrm{df}=14, \mathrm{p}=$ 0.016). The variation in biomass is illustrated in Fig. 2B and summarized in Table 3. Overall, the mean and median values per sample were 7.78 and $0.001 \mathrm{~g} \mathrm{WM} 0.049 \mathrm{~m}^{-2}$, respectively. Only 20 out of 150 samples had higher biomass than the overall average of $7.78 \mathrm{~g} \mathrm{WM} 0.049 \mathrm{~m}^{-2}$. The highest total biomasses (g WM $0.49 \mathrm{~m}^{-2}$ ) were found at Stns 3 (120.4), 5 (144.2), 13 (141.9), 15 (135.1) and 16 (357.4).
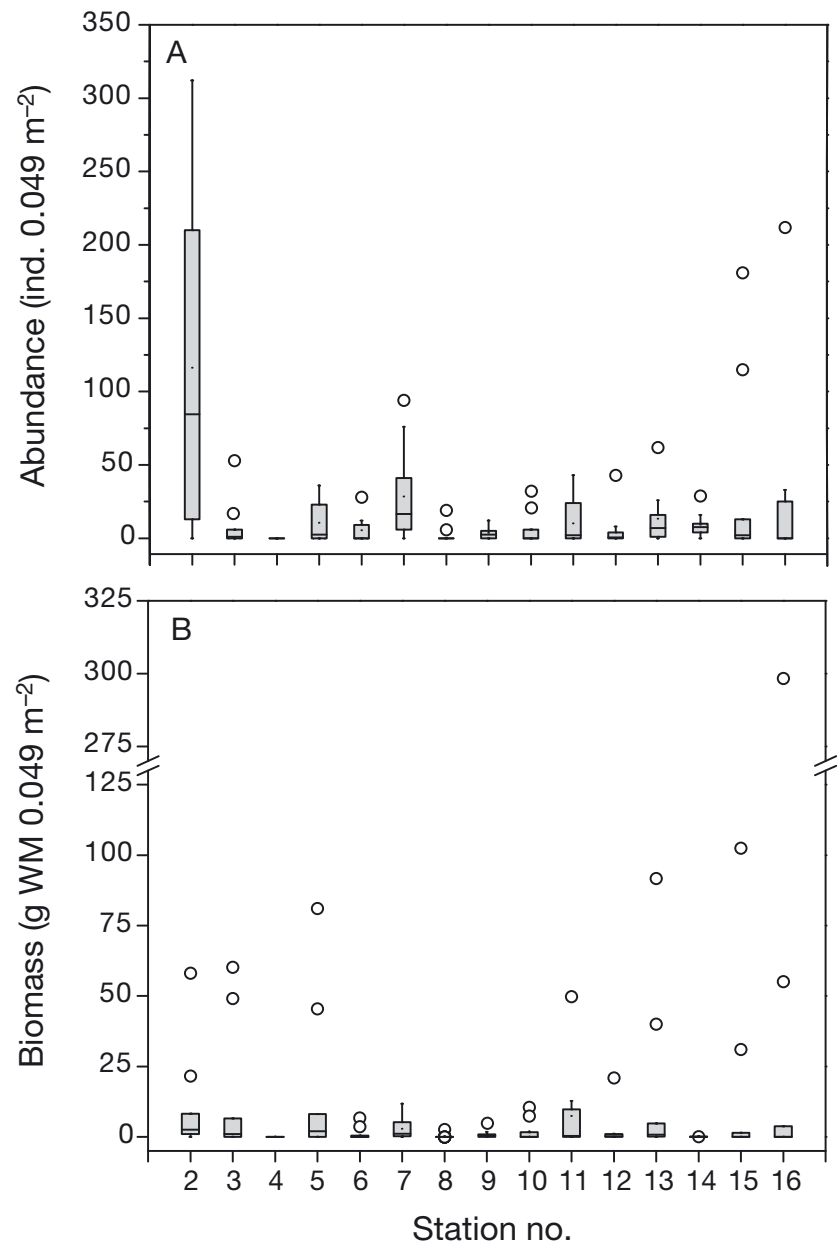

Fig 2. Mytilus edulis. Box plots of (A) abundance and (B) biomass of blue mussels in the mid-intertidal zone in the Godthåbsfjord system. The box represents the 25 to $75 \%$ interquartile range (IQR). Whiskers extend from maximum to minimum observations excluding outliers $(0)$, which are more than $1.5 \times$ IQR above the 75th percentile or $1.5 \times$ IQR below the 25th percentile. The horizontal line within the IQR represents the median. WM: wet mass

The lowest biomasses were found at Stns $4(0.0), 8$ (2.9) and 14 (0.55).

There were no statistically significant correlations (Pearsons) of abundance or biomass (mean ranks) to the overall habitat characteristics of the sampling stations (algae cover, rugosity, wind exposure, ice exposure).

Besides Mytilus, the invertebrate community in the intertidal zone consisted of relatively few invertebrate species, barnacles Semibalanus balanoides and periwinkles Littorina sp. being the most abundant. Macroalgae Ascophyllum nodosum were most abundant at sheltered sites, whereas Fucus vesiculosus inhabited exposed localities. We did not encounter 
Table 3. Mytilus edulis. Summary statistics on abundance and biomass of blue mussels at the 15 sampling stations (10 replicates per station) in the Godthåbsfjord system, SW Greenland

\begin{tabular}{|c|c|c|c|c|c|c|c|c|c|c|c|c|}
\hline \multirow[t]{2}{*}{ Stn } & \multicolumn{6}{|c|}{ Abundance (ind. $0.049 \mathrm{~m}^{-2}$ ) } & \multicolumn{6}{|c|}{-Wet mass (g $\left.0.049 \mathrm{~m}^{-2}\right)$} \\
\hline & Average & $\mathrm{SD}$ & Median & Min. & Max. & Sum & Average & $\mathrm{SD}$ & Median & Min. & Max. & Sum \\
\hline 2 & 116.2 & 115.9 & 84.5 & 0 & 312 & 1162 & 9.86 & 18.15 & 2.58 & 0 & 58.08 & 98.55 \\
\hline 3 & 8.1 & 16.6 & 1 & 0 & 53 & 81 & 12.05 & 22.73 & 1.00 & 0 & 60.25 & 120.46 \\
\hline 4 & 0 & & 0 & 0 & 0 & 0 & 0 & & 0 & 0 & 0 & 0 \\
\hline 5 & 10.5 & 14.5 & 2.5 & 0 & 36 & 105 & 14.42 & 27.22 & 1.94 & 0 & 81.05 & 144.16 \\
\hline 6 & 5.4 & 9.1 & 0 & 0 & 28 & 54 & 1.08 & 2.29 & 0.00 & 0 & 6.73 & 10.81 \\
\hline 7 & 28.4 & 32.8 & 16.5 & 0 & 94 & 284 & 2.86 & 3.83 & 1.05 & 0 & 11.76 & 28.60 \\
\hline 8 & 2.5 & 6.1 & 0 & 0 & 19 & 25 & 0.29 & 0.84 & 0.00 & 0 & 2.67 & 2.90 \\
\hline 9 & 3.7 & 4.2 & 2.5 & 0 & 12 & 37 & 0.97 & 1.49 & 0.62 & 0 & 4.91 & 9.70 \\
\hline 10 & 5.9 & 11.3 & 0 & 0 & 32 & 59 & 1.97 & 3.81 & 0.00 & 0 & 10.56 & 19.70 \\
\hline 11 & 10.2 & 15.1 & 2 & 0 & 43 & 102 & 7.39 & 15.60 & 0.32 & 0 & 49.78 & 73.87 \\
\hline 12 & 5.8 & 13.3 & 0.5 & 0 & 43 & 58 & 2.40 & 6.54 & 0.23 & 0 & 20.99 & 24.00 \\
\hline 13 & 13.4 & 19.0 & 7 & 0 & 62 & 134 & 14.19 & 29.90 & 0.75 & 0 & 91.76 & 141.90 \\
\hline 14 & 9.2 & 8.2 & 7.5 & 0 & 29 & 92 & 0.05 & 0.07 & 0.03 & 0 & 0.20 & 0.55 \\
\hline 15 & 32 & 63.2 & 2 & 0 & 181 & 320 & 13.51 & 32.75 & 0.01 & 0 & 102.51 & 135.13 \\
\hline 16 & 27 & 66.1 & 0 & 0 & 212 & 270 & 35.74 & 93.90 & 0.00 & 0 & 298.46 & 357.42 \\
\hline Pooled & 18.6 & 47.5 & 1 & 0 & 312 & 2783 & 7.78 & 29.20 & 0.00 & 0 & 298.46 & 1167.73 \\
\hline
\end{tabular}

any invertebrate predators in the intertidal zone at any of the stations. However, at Stn 13, starfish Asterias sp., a common predator of mussels, was registered just below the low water mark. The limpet Tectura sp. was found sporadically in the lowest part of the intertidal. The sea urchin Strongylocentrotus sp. was abundant below the intertidal at several stations. Limpets and sea urchins have been reported to graze on mussel spat in the low shore (Seed 1969).

\section{Age structure and mortality}

Of the original 25 tagged mussels, 9 were recovered from the intertidal zone in June 2011, 1 yr after tagging. The formation of annual growth increments was confirmed; all individuals showed one distinct growth zone followed by a conspicuous growth check close to the shell margin. Recent shell growth was seen as a narrow band at the shell edge. This result agrees with a recent study of oxygen isotope ratios in the shell of Mytilus edulis in the Godthåbsfjord, indicating that growth checks are formed during winter growth cessation (Versteegh et al. 2012).

The age structure varied significantly between the 15 stations in the Godthåbsfjord system (Kruskal-Wal- lis, $\left.\chi^{2}=966.7, \mathrm{df}=13, \mathrm{p}<0.0001\right)$. Most stations were dominated by young individuals $\leq 3 \mathrm{yr}$ of age ( $<15 \mathrm{~mm}$ shell length), which constituted $82 \%$ of the total dataset. The observed maximum age in the quantitative samples varied from 3 (Stn 14) to $15 \mathrm{yr}$ (Stns 5, 11 and 16; Fig. 3A). Even though individuals from age classes $>3 \mathrm{yr}$ were somewhat unevenly dis-

\author{
(1)
}

\section{A}

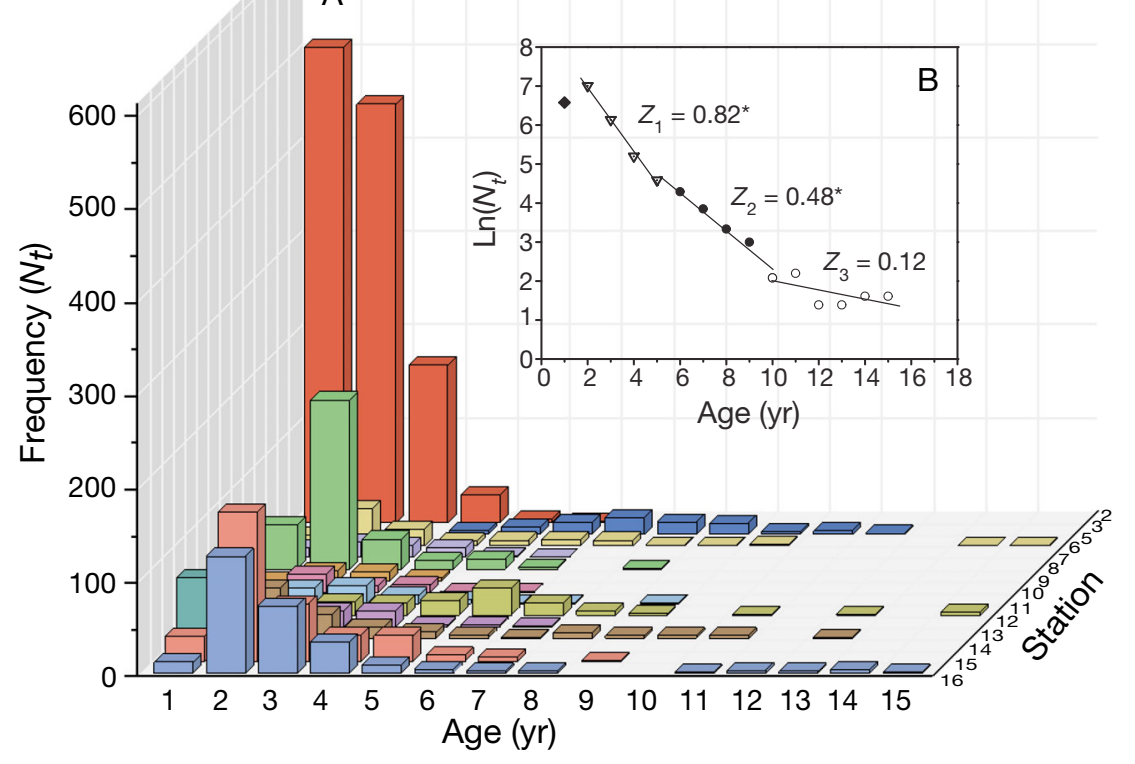

Fig. 3. Mytilus edulis. (A) Number of individuals of different age classes in 10 replicate samples $\left(N_{t}\right)$ at 15 stations in the mid-intertidal zone in the Godthåbsfjord, SW Greenland, and (B) annual instantaneous mortality rates (Z) estimated from the pooled data set showing a gradual decrease in mortality rate with increasing age. Statistically significant $Z\left({ }^{*} \mathrm{p}<0.05\right.$, linear regression) 
Table 4. Mytilus edulis. Growth model parameters for mussels from the sampling localities in the Godthåbsfjord system, and a common growth model including size-age data from all stations. $S_{\infty}$ : asymptotic shell length (mm); $t_{*}$ : age-at-growth inflexion; $T$ : time required to grow from zero to $S_{\infty}$ at maximum growth rate; $m$ : shape factor for Richards' curves (Eq. 1); $a$ and $b$ are parameters in the error term (Eq. 3). S: shell length. See 'Results' section for statistics. Values in parentheses refer to supplementing qualitative samples (see 'Materials and methods')

\begin{tabular}{|c|c|c|c|c|c|c|c|c|c|}
\hline Stn & $S_{\infty}$ & $t_{*}$ & $T$ & $m$ & $a$ & $b$ & Max. age (yr) & Max. $S(\mathrm{~mm})$ & No. of ind. \\
\hline 2 & 32.61 & 3.70 & 3.78 & 2.31 & 0.27 & 1.09 & $6(10)$ & $45.4(51.7)$ & $1162(8)$ \\
\hline 3 & 47.48 & 10.66 & 9.10 & 8.99 & 0.06 & 1.33 & $12(16)$ & $46.4(55.3)$ & 81 (16) \\
\hline 5 & 52.59 & 5.40 & 7.90 & 1.59 & 0.27 & 0.93 & 15 & 66.2 & 105 \\
\hline 6 & 59.88 & 4.98 & 7.58 & 1.23 & 0.24 & 0.96 & $6(14)$ & $25.0(67.8)$ & 54 (9) \\
\hline 7 & 28.92 & 4.56 & 5.21 & 3.04 & 0.26 & 0.92 & 8 & 32.9 & 284 \\
\hline 8 & 61.94 & 6.84 & 4.36 & 5.33 & 0.20 & 1.06 & 4 & 18.3 & 25 \\
\hline 9 & 72.66 & 6.01 & 6.10 & 2.24 & 0.34 & 0.78 & $6(19)$ & $31.7(79.1)$ & $37(12)$ \\
\hline 10 & 131.10 & 6.06 & 25.38 & 0.35 & 0.75 & 0.49 & $9(17)$ & $35.4(79.8)$ & 59 (15) \\
\hline 11 & 42.00 & 6.44 & 13.29 & 1.48 & 0.23 & 0.86 & 15 & 41.0 & 102 \\
\hline 12 & 62.67 & 4.94 & 10.10 & 0.91 & 0.37 & 0.76 & 7 & 35.0 & 58 \\
\hline 13 & 42.02 & 3.70 & 7.14 & 1.21 & 0.44 & 0.75 & 13 & 54.4 & 134 \\
\hline 14 & 91.35 & 6.71 & 5.12 & 2.61 & 0.30 & 0.66 & 3 & 10.0 & 92 \\
\hline 15 & 41.21 & 3.69 & 7.08 & 1.18 & 0.42 & 0.72 & 9 & 39.1 & 320 \\
\hline 16 & 51.82 & 4.28 & 6.02 & 1.43 & 0.30 & 0.99 & $15(17)$ & 72.5 & $270(12)$ \\
\hline All common & 52.90 & 4.11 & 10.01 & 0.73 & 0.31 & 1.00 & 15 (19) & $72.5(79.8)$ & $2783(72)$ \\
\hline
\end{tabular}

tributed among stations, the pooled dataset followed a negative exponential model $\left(N_{t}=N_{0} \cdot \mathrm{e}^{-Z \cdot t}\right)$ making it possible to estimate annual mortality rates. Close examination revealed 3 phases during the life history of Mytilus edulis: (1) age 2 to $5 \mathrm{yr}: Z=0.82(\mathrm{p}<0.01)$; (2) age 5 to $10 \mathrm{yr}: Z=0.48(\mathrm{p}<0.01)$; and (3) age 10 to $15 \mathrm{yr}: Z=0.12$ ( $\mathrm{p}>0.05$, ns) (Fig. 3b). Age class $1 \mathrm{yr}$ was excluded in the analysis due to an apparent underrepresentation in the dataset.

\section{Growth patterns}

Shell length-at-age data from 14 of the 15 stations where Mytilus edulis were found were used to estimate growth models. The initial growth model involved 6 parameter values for each group by maximizing the joint likelihood. We reduced this model in single steps to test if some or all parameters could be applied to all groups: (1) common $a$ and $b_{i} \chi^{2}=181.9$, $\mathrm{p}<0.0001$, AIC 11399.9 $\rightarrow$ 11529.8), (2) common $S_{\infty i}$ $\chi^{2}=68.0, \mathrm{p}<0.0001$, AIC 11399.9 $\rightarrow 11441.9$, (3) common $m_{i} \chi^{2}=69.7, \mathrm{p}<0.0001$, AIC $11399.9 \rightarrow 11443.7$ ), (4) common $T_{i} \chi^{2}=182.2, \mathrm{p}<0.0001$, AIC $11399.9 \rightarrow$ 11556.1, (5) common $t_{* i} \chi^{2}=79.0, \mathrm{p}<0.0001$, AIC $11399.9 \rightarrow 11452.9$, (6) All common; $\chi^{2}=1284.7, p<$ 0.0001 , AIC $11399.9 \rightarrow 12528.6$. In its essence, this means that growth differed between stations and that no parameters could be fitted by the same values to all groups without changing the individual growth curve characteristics significantly. The parameters of the initial (and best fit) growth model are summa- rized in Table 4, including maximum observed age. Growth curves are illustrated in Fig. 4. Growth patterns seem quite similar until an age of 5 yr (except Stns 3 and 11), where the average shell length is 15 to $30 \mathrm{~mm}$. Hereafter, the differences between stations become clearer, as seen in the different estimates of $S_{\infty}$. Parameters of a general growth model fitted to the pooled dataset are also given in Table 4, providing an overall baseline of growth and growth variation in the Godthåbsfjord system.

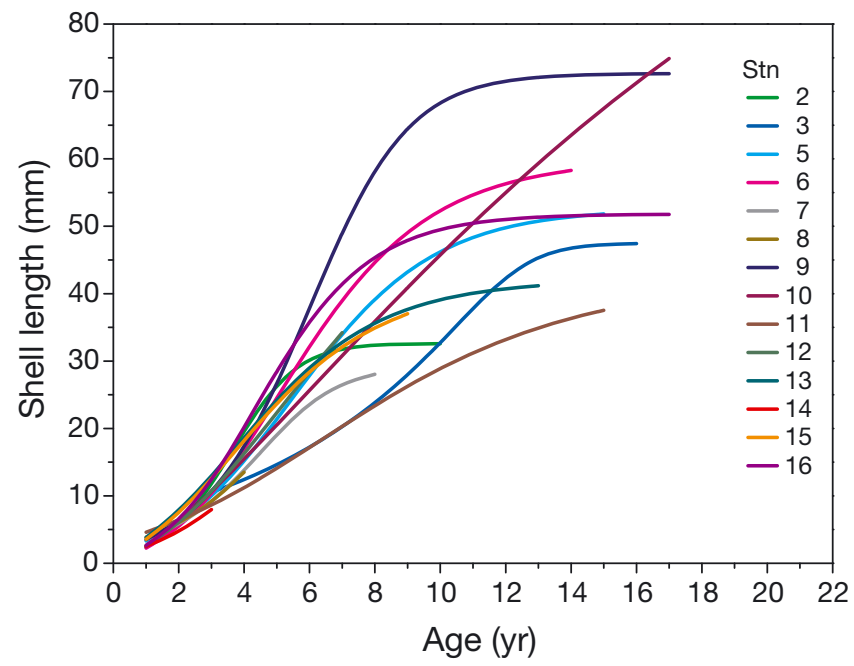

Fig. 4. Mytilus edulis. Growth curves (Eq. 1) fitted to size-atage data from 14 mid-intertidal stations in the Godthåbsfjord system, SW Greenland. See Table 4 for parameter values 


\section{DISCUSSION}

\section{Abundance and biomass}

We did not observe any invertebrate predators in the intertidal zone in the Godthåbsfjord. Still, abundance of mussels in the mid-intertidal in the Godthåbsfjord was patchy and generally low compared to the dense concentrations found in some soft bottom and rocky intertidal habitats in temperate areas, which may reach several thousand ind. $\mathrm{m}^{-2}$ (Suchanek 1978, Craeymeersch et al. 1986, Asmus 1987, Gardner \& Thomas 1987). Likewise, the highest intertidal biomasses reported in the literature are orders of magnitude higher than in the Godthåbsfjord and may be as high as $>5000 \mathrm{~g} \mathrm{WM} \mathrm{m}^{-2}$ as reported from mussel beds in the North Sea (Asmus 1987). Such dense mussel populations can attract bottom foraging birds (e.g. Sukhotin et al. 2008), potentially affecting the population structure of the mussels. Some local concentrations of wintering eiders are found in the Godthåbsfjord (Merkel et al. 2002, Blicher et al. 2011); however, Mytilus edulis is not a dominant food source for eiders, which primarily forage on soft bottom fauna (Merkel et al. 2007). So neither the diet nor the number of birds suggests that they are capable of controlling the mussel population on a fjord scale.

The patchy distribution and the concentration of mussels in crevices, in association with boulders and in macroalgae beds, is a common phenomenon on exposed rocky shores. These mesoscale habitats may provide refuge from strong waves, temperature extremes and ice scouring (Bergeron \& Bourget 1986, Bertness et al. 1999). The lack of simple correlations to habitat characteristics suggests that Mytilus edulis abundance is affected by variation occurring on a different scale than the $10 \mathrm{~m}$ scale used in our visual characterization. In fact, the variation in abundance between replicates was not significantly different from the variation between stations ( $F$-ratio test; $F_{\text {station }}=7.28, F_{\text {replicate }}=2.53, \mathrm{p}>0.1$ ), supporting the notion that coastal heterogeneity at a scale $<20 \mathrm{~cm}$ is important in the intertidal zone (Archambault \& Bourget 1996).

Considering the absence of invertebrate predators (i.e. whelks, starfish, crabs) such as those reported from rocky shores in temperate areas (Seed 1969, Menge 2000), the low and patchy abundance of Mytilus edulis in the rocky intertidal in the Godthåbsfjord may indicate that its abundance and distribution is primarily controlled by the physical properties of the habitat. Winter temperature appears to be an important factor since there are several days each year when temperature exceeds the lower limits of survival $\left(-12.5\right.$ to $-17.5^{\circ} \mathrm{C}$, depending on size; Table 5). Obviously crevices and macroalgae may be important microhabitats protecting against temperature extremes (Helmuth et al. 2010). Scouring by ice is also an important factor in some parts of the Godthåbsfjord. In some protected parts of the fjord fast ice forms in December to January and melts again in May. Despite tidal-induced scouring along the shore, fast ice does not seem to influence the tidal community negatively, as dense macroalgae beds can be found. In fact, an intertidal ice foot may actually provide insulation against temperature extremes during critical periods (Scrosati \& Eckersley 2007). However, glacier ice leaves the fjord predominantly along the northern shore, and some stretches are strongly scoured with no form for biota except between boulder and in deep crevices. Both temper-

Table 5. Summary statistics on winter air temperatures in the inner (Kapissillit 532) and outer (Nuuk 522) part of the Godthåbsfjord system. See Fig. 1 for geographic position

\begin{tabular}{|c|c|c|c|c|c|c|}
\hline Climate station & Year & $\begin{array}{l}\text { No. of d (h) } \\
\quad<-10^{\circ} \mathrm{C}\end{array}$ & $\begin{array}{l}\text { No. of d (h) } \\
<-12.5^{\circ} \mathrm{C}\end{array}$ & $\begin{array}{l}\text { No. of d (h) } \\
<-17.5^{\circ} \mathrm{C}\end{array}$ & $\begin{array}{c}\text { Min. temp. } \\
\left({ }^{\circ} \mathrm{C}\right)\end{array}$ & $\begin{array}{l}\text { Max. temp. } \\
\left({ }^{\circ} \mathrm{C}\right)\end{array}$ \\
\hline \multirow[t]{5}{*}{ Kapissillit 532} & 2007 & $71(1178)$ & $46(662)$ & 14 (183) & -23.1 & 20.5 \\
\hline & 2008 & $90(1747)$ & 75 (1398) & 45 (705) & -31.2 & 21.3 \\
\hline & 2009 & 91 (1487) & 62 (899) & 16 (203) & -24.6 & 18.8 \\
\hline & 2010 & 23 (329) & 16 (153) & $0(0)$ & -17.2 & 21.8 \\
\hline & 2011 & 136 (2336) & $97(1368)$ & $21(175)$ & -21.3 & 19.7 \\
\hline \multirow[t]{5}{*}{ Nuuk 522} & 2007 & $55(871)$ & $23(340)$ & $0(0)$ & -16.8 & 19.1 \\
\hline & 2008 & 63 (1252) & 52 (919) & $12(214)$ & -25.6 & 19.2 \\
\hline & 2009 & $48(765)$ & $19(300)$ & $4(47)$ & -18.7 & 17.9 \\
\hline & 2010 & $12(171)$ & $6(42)$ & $0(0)$ & -15.6 & 21.7 \\
\hline & 2011 & 66 (1047) & $24(335)$ & $2(15)$ & -19.3 & 15.9 \\
\hline
\end{tabular}


ature and ice scour vary between years and on a decimeter scale. At present, such high-resolution environmental data are not available.

We did not assess the potential species interactions of the sessile epibenthos in this study. Physical stressors (especially wave exposure) are known to affect interspecific relations and the relative abundance of species. This may occur as direct effects on these organisms, or indirectly through influences on their predators (Menge 1976). In an ice-exposed habitat in the Gulf of St. Lawrence, Canada, a distinct space partitioning of intertidal crevice refuges by Semibalanus balanoides, Fucus vesiculosus and Mytilus edulis has been described (Bergeron \& Bourget 1986). Similar patterns are likely to exist in the Godthåbsfjord system, but it is not clear how the total absence of intertidal invertebrate predators may affect species interactions along physical stress gradients.

\section{Growth and mortality}

The growth pattern of Mytilus edulis, obtained from size-age data, differed significantly between stations in the Godthåbsfjord. Differences in food conditions, temperature and salinity may be responsible. Meso-scale variation in food conditions and air and sea temperature are difficult to assess. In terms of salinity, the glacier-fjord-ocean transect provides a clear gradient. A recent study reported summer minimum values as low as $<10$ psu in surface waters in the inner part of Godthåbsfjord during peak melt water runoff and suggested that $M$. edulis ceased growing at salinities < 19 psu (Versteegh et al. 2012). However, our data did not reveal any trends in the overall growth patterns that could be related to inhibition by the low salinity in the inner part of the fjord. In fact, the observed local growth variation covered more or less the entire range of growth patterns found in intertidal populations in the Barents and White Sea, and West Greenland (Theisen 1973, Sukhotin et al. 2007 and references therein). This is illustrated in
Fig. 5, where the general growth model for M. edulis in the Godthåbsfjord is applied (see Table 4). In this comparison it is also evident that intertidal growth conditions seem to be more favorable in the temperate North Sea (Denmark, Germany, Netherlands) (Craeymeersch et al. 1986, Asmus 1987, MunchPetersen \& Kristensen 2001). Large local variation is also apparent in temperate areas as seen in the comparison of growth of 2 nearby intertidal populations in SW England, one growing remarkably faster than the other (Fig. 5) (Bayne \& Worrall 1980, Gardner et al. 1993). Thus, the large scale geographical variation seems to be in the same range as what can be observed locally, again emphasizing the importance of small-scale processes in controlling population

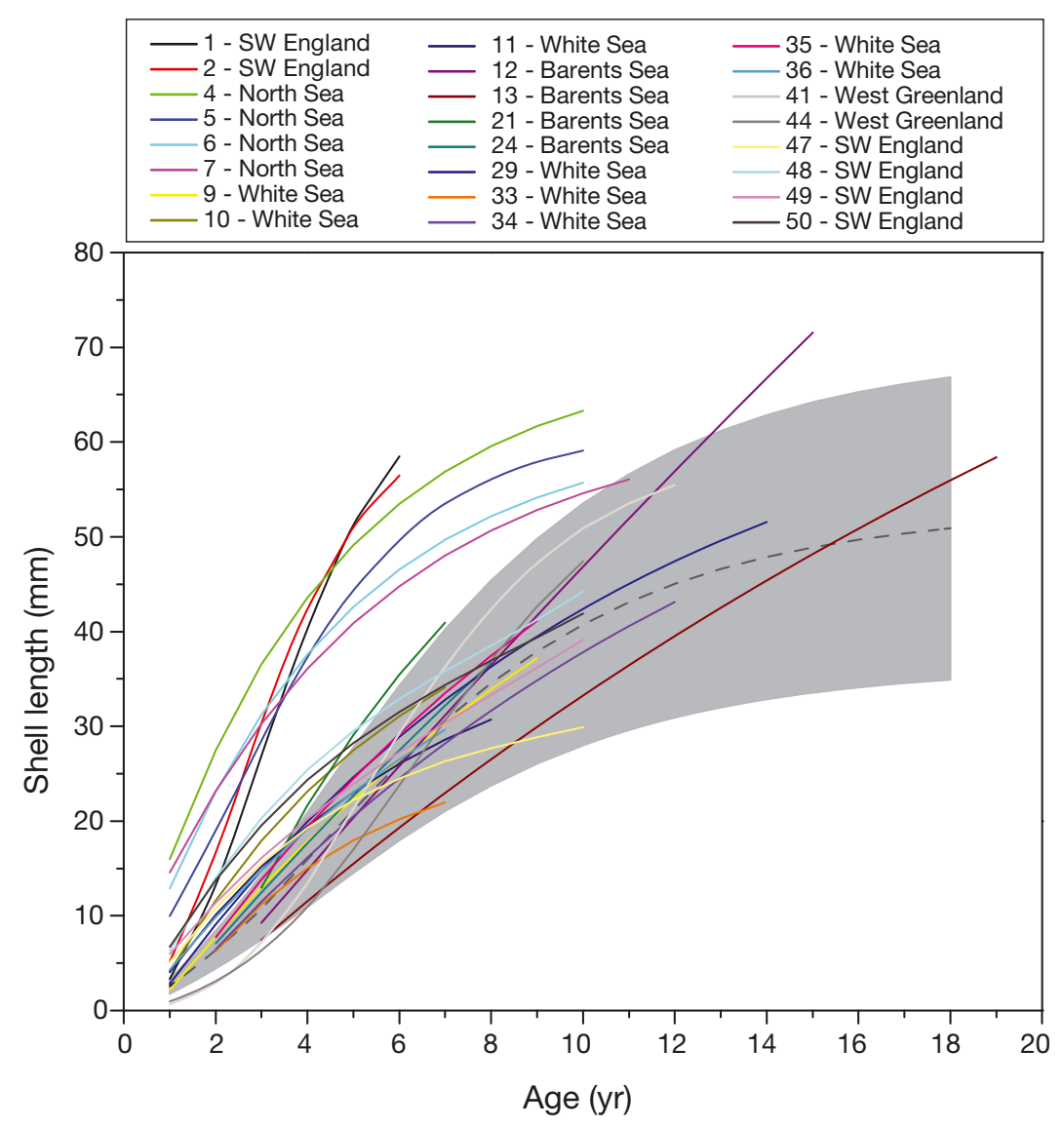

Fig. 5. Mytilus edulis. Growth curves of blue mussels from different intertidal locations in the North Atlantic. The growth model was estimated using the pooled data set from the mid-intertidal zone in the Godthåbsfjord, SW Greenland. The grey dashed line represents the actual growth curve (Eq. 1), and the grey shaded area illustrates the standard deviation (Eq. 3). See Table 4 for parameter values. Data from literature: 1-2: Bayne \& Worrall (1980); 4: Munch-Petersen \& Kristensen (2001); 5: Craeymeersch et al. (1986); 6: Asmus (1987); 7: Sukhotin et al. (2006); 9-11: Maximovich (1989); 12-13: Sukhotin et al. (2006); 21-36: Sukhotin et al. (2007); 41-44: Theisen (1973), re-iterated from original data; 47-50: Gardner et al. (1993) 
structure of $M$. edulis in the intertidal zone. However, fast growth may not be crucial for attaining spatial dominance of $M$. edulis. Recruitment and mortality rates can be major contributing factors (Seed 1969).

The spatial differences in age distribution of Mytilus edulis (Fig. 3) suggest a rather patchy settling and/or recruitment of mussels in the Godthåbsfjord. Exogenous processes such as wind and tidal currents in the period with pelagic larval phase and spatfall may be the major causes of inter-annual variation at a given site and local variation (McQuaid \& Phillips 2000, Becker et al. 2007). However, the pooled dataset results in an age distribution from which it is reasonable to assume stable annual recruitment on fjord scale. The lower than expected abundance of age class 1 is interpreted as either ineffective sampling of the smallest size-group or primary settling/recruitment outside the intertidal zone. Secondary settling is common for $M$. edulis and may contribute to the observed age structure (e.g. Bayne 1964). Therefore, age class 1 was excluded in the analysis of mortality. The annual mortality rates extracted from the age-distribution suggest 3 phases and gradual reductions in mortality rate with increasing age (Fig. 3B). The annual mortality rate up to an age of $5 \mathrm{yr}(Z=0.82)$ is high compared to estimates from sub-tidal bivalve populations in the Arctic, which generally have adult mortality rates of $Z<0.3 \mathrm{yr}^{-1}$ (Høpner Petersen 1978, Sejr \& Christensen 2007, Begum et al. 2010). Estimates of $Z$ in non-exploited intertidal $M$. edulis populations in temperate areas vary from 0.3 to $>1 \mathrm{yr}^{-1}$ (Seed 1969, Gardner \& Thomas 1987, Munch-Petersen \& Kristensen 2001). Considering the fact that these temperate populations are subject to a high degree of predation, the mortality rates estimated for $M$. edulis in Godthåbsfjord, where invertebrate predators are absent, may seem surprisingly high. This is most likely linked to the higher degree of physical stress caused by low winter air temperature and ice scouring in this subArctic habitat. The role of wave forces in these inshore habitats is uncertain. Despite potential negative effects of wave exposure, $M$. edulis is known to be capable of forming dense beds on wave exposed sites on open Atlantic shores in temperate areas despite substantial wave dislodgement (e.g. Seed 1969, Suchanek 1978) and at more sheltered localities to be affected positively by increases in wave forces (Westerbom \& Jattu 2006). Therefore, any dominating negative effect of wave exposure on $M$. edulis in the Godthåbsfjord might be considered less likely.

The reduction in annual mortality rate with increasing age may be directly linked to a higher resistance to potentially detrimental extreme events as mussels grow larger (e.g. Williams 1970, Kennedy 1976). In the study area typical winter minimum air temperature is -15 to $-30^{\circ} \mathrm{C}$. The lower limit of survival for Mytilus edulis is approximately -12.5 to $-17.5^{\circ} \mathrm{C}\left(\mathrm{LT}_{50}\right)$ but depends on several factors such as exposure time, salinity and individual size (Williams 1970, Bourget 1983). However, the decrease in mortality rate with increasing age can also be indirectly coupled to habitat type. Crevices and boulders provide protection against low temperatures (wind chill), ice scouring and wave action, and macroalgae beds and an intertidal ice foot provides insulation against temperature extremes (Bertness et al. 1999, Scrosati \& Eckersley 2007). Higher mortality outside these refuges would lead to only the most favorable habitats with low mortality being represented in the group of large/old mussels, which was similar to our observations in the Godthåbsfjord system.

\section{CONCLUSIONS}

This paper provides the most detailed description to date of Mytilus edulis population structure in the Arctic. Contrary to temperate areas, invertebrate predators are absent in the intertidal zone in the Godthåbsfjord. Despite this, abundance and biomass of $M$. edulis is generally low. Our results indicate that low winter temperatures combined with local ice scouring cause high mortality of juveniles. At mesoscale habitats where minimum temperature is modified and ice scouring is minimal, specimens can survive although growth rates are slower compared to most temperate sites. Crevices, boulders and macroalgae beds are important refuges during detrimental extreme events but provide variable growth conditions.

The apparent importance of winter air temperature and ice scouring on the Mytilus edulis population structure combined with lack of predatory regulation suggest that the $M$. edulis population in the Greenland intertidal has a strong potential for increased abundance at both meso-scale within individual fjords but also a general range expansion along the West Greenland coast.

Acknowledgements. We thank L. Heilmann and F. Heinrich for their help in the field. T. Balsby is thanked for statistical advice. The study was financially supported by the Greenland Climate Research Centre, the Danish Ministry of the Environment (Dancea), Aarhus University, the Commission for Scientific Research in Greenland, the Ministry of Educa- 
tion, Research and Nordic cooperation (IIN) and Aage V Jensen Charity Foundation, and is a part of the Greenland Ecosystem Monitoring program (www.g-e-m.dk) and the Arctic Science Partnership (http://asp-net.org/).

\section{LITERATURE CITED}

ACIA (2004) Impacts of a warming Arctic: Arctic climate impact assessment, Cambridge University Press, Cambridge

Archambault P, Bourget E (1996) Scales of coastal heterogeneity and benthic intertidal species richness, diversity and abundance. Mar Ecol Prog Ser 136:111-121

Arendt KE, Juul-Pedersen T, Mortensen J, Blicher ME, Rysgaard S (2013) A 5-year study of seasonal patterns in mesozooplankton community structure in a subArctic fjord reveals dominance of Microsetella norvegica (Crustacea, Copepoda). J Plankton Res 35:105-120 doi: 10.1093/plankt/fbs087

> Asmus H (1987) Secondary production of an intertidal mussel bed community related to its storage and turnover compartments. Mar Ecol Prog Ser 39:251-266

Bayne BL (1964) Primary and secondary settlement in Mytilus edulis L. (Mollusca). J Anim Ecol 33:513-523

Bayne BL, Worrall CM (1980) Growth and production of mussels Mytilus edulis from two populations. Mar Ecol Prog Ser 3:317-328

Becker BJ, Levin LA, Fodrie FJ, McMillan FA (2007) Complex larval connectivity patterns among marine invertebrate populations. Proc Natl Acad Sci USA 104: 3267-3272

> Begum S, Basova L, Heilmayer O, Philipp EER, Abele D, Brey T (2010) Growth and energy budget models of the bivalve Arctica islandica at six different sites in the northeast Atlantic realm. J Shellfish Res 29:107-115

> Berge J, Johnsen G, Nilsen F, Gulliksen B, Slagstad D (2005) Ocean temperature oscillations enable reapperance of blue mussels Mytilus edulis in Svalbard after a 1000 year absence. Mar Ecol Prog Ser 303:167-175

> Bergeron P, Bourget E (1986) Shore topography and spatial partitioning of crevice refuges by sessile epibenthos in an ice disturbed environment. Mar Ecol Prog Ser 28: 129-145

Bertness MD, Leonard GH, Levine JM, Schmidt PR, Ingraham AO (1999) Testing the relative contribution of positive and negative interactions in rocky intertidal communities. Ecology 80:2711-2726

Blicher ME, Rasmussen LM, Sejr MK, Merkel F, Rysgaard S (2011) Abundance and energy requirements of eiders (Somateria spp.) suggest high predation pressure on macrobenthic fauna in a key wintering habitat in SW Greenland. Polar Biol 34:1105-1116

Bourget E (1983) Seasonal variations of cold tolerance in intertidal mollusks and relation to environmental conditions in the St. Lawrence Estuary. Can J Zool 61: 1193-1201

> Craeymeersch JA, Herman PMJ, Meire PM (1986) Secondary production of an intertidal mussel (Mytilus edulis L.) population in the Eastern Scheldt (S.W. Netherlands). Hydrobiologia 133:107-115

Gardner JPA, Thomas MLH (1987) Growth, mortality and production of organic matter by a rocky intertidal population population of Mytilus edulis in the Quoddy region of the Bay of Fundy. Mar Ecol Prog Ser 39:31-36
Gardner JPA, Skibinski DOF, Bajdik CD (1993) Shell growth and viability differences between the marine mussels Mytilus edulis (L.), Mytilus galloprovincialis (Lmk.), and their hybrids from two sympatric populations in S.W. England. Biol Bull 185:405-416

Helmuth B, Broitman BR, Yamane L, Gilman SE, Mach K, Mislan KAS, Denny MW (2010) Organismal climatology: analyzing environmental variability at scales relevant to physiological stress. J Exp Biol 213:995-1003

> Herbert RJH, Southward AJ, Clarke RT, Sheader M, Hawkins SJ (2009) Persistent border: an analysis of the geographic boundary of an intertidal species. Mar Ecol Prog Ser 379:135-150

> Høpner Petersen G (1978) Life cycles and population dynamics of marine benthic bivalves from the Disco Bugt area of West Greenland. Ophelia 17:95-120

> Jones SJ, Mieszkowska N, Wethey DS (2009) Linking thermal tolerances and biogeography: Mytilus edulis (L.) at its southern limit on the east coast of the United States. Biol Bull 217:73-85

Jones SJ, Lima FP, Wethey DS (2010) Rising environmental temperatures and biogeography: poleward range contraction of the blue mussel, Mytilus edulis L., in the western Atlantic. J Biogeogr 37:2243-2259

Kennedy VS (1976) Desiccation, higher temperatures and upper intertidal limits of three species of sea mussels (Mollusca-Bivalvia) in New Zealand. Mar Biol 35: $127-137$

Lebreton J, Burnham K, Clobert J, Anderson D (1992) Modelling survival and testing biological hypothesis using marked animals: a unified approach with case studies. Ecol Monogr 62:67-118

Maximovich NV (1989) Statistical comparison of growth curves. Vestnik LGU Ser 3:18-25 (in Russian)

> McQuaid CD, Phillips TE (2000) Limited wind-driven dispersal of intertidal mussel larvae: in situ evidence from the plankton and the spread of the invasive species Mytilus galloprovincialis in South Africa. Mar Ecol Prog Ser 201:211-220

> Menge BA (1976) Organization of New England rocky intertidal community - role of predation, competition, and environmental heterogeneity. Ecol Monogr 46:355-393

> Menge BA (2000) Top-down and bottom-up community regulation in marine rocky intertidal habitats. J Exp Mar Biol Ecol 250:257-289

Merkel FR, Mosbech A, Boertmann D, Grøndahl L (2002) Winter sea-bird distribution and abundance off southwestern Greenland, 1999. Polar Res 21:17-36

Merkel FR, Jamieson SE, Falk K, Mosbech A (2007) The diet of common eiders wintering in Nuuk, Southwest Greenland. Polar Biol 30:227-234

Mieszkowska N, Kendall MA, Hawkins SJ, Leaper R, Williamson P, Hardman-Mountford NJ, Southward AJ (2006) Changes in the range of some common rocky shore species in Britain-a response to climate change? Hydrobiologia 555:241-251

Mortensen J, Lennert K, Bendtsen J, Rysgaard S (2011) Heat sources for glacial melt in a sub-arctic fjord (Godthåbsfjord) in contact with the Greenland Ice sheet. J Geophys Res 116:C01013

Mosbech A, Anthonsen K, Blyth A, Boertmann D and others (2000) Environmental oil spill sensitivity atlas for the West Greenland Coastal Zone. The Danish Energy Agency, Ministry of Environment and Energy, Copenhagen 
Munch-Petersen S, Kristensen PS (2001) On the dynamics of the stocks of blue mussels in the Danish Wadden Sea. Hydrobiologia 465:31-43

Richards F (1959) A flexible growth model for empirical use. J Exp Bot 10:290-300

Ross K, Thorpe J, Norton T, Brand T (2001) An assessment of some methods for tagging the great scallop, Pecten maximus. J Mar Biol Assoc UK 81:975-977

Sagarin RD, Barry JP, Gilman SE, Baxter CH (1999) Climaterelated change in an intertidal community over short and long time scales. Ecol Monogr 69:465-490

Scrosati R, Eckersley LK (2007) Thermal insulation of the intertidal zone by the ice foot. J Sea Res 58:331-334

Seed R (1969) The ecology of Mytilus edulis L. (Lamellibranchiata) on exposed rocky shores. II. Growth and mortality. Oecologia 3:317-350

Seed R, Suchanek T (1992) Population and community ecology of Mytilus. In: Gosling EM (ed) The mussel Mytilus: ecology, physiology, genetics and culture. Elsevier, Amsterdam, p 87-169

Sejr MK, Christensen PB (2007) Growth, production and carbon demand of macrofauna in Young Sound, with special emphasis on the bivalves Hiatella arctica and Mya truncata In: Rysgaard S, Glud RN (eds) Carbon cycling in Arctic marine ecosystems: case study Young Sound. Book 58. Meddelelser om Grønland, Bioscience, Copenhagen, p 122-135

Suchanek TH (1978) The ecology of Mytilus edulis L. in exposed rocky intertidal communities. J Exp Mar Biol Ecol 31:105-120

Sugden L, Driver E, Kingsley M (1981) Growth and energy consumption of captive mallards. Can J Zool 59: $1567-1570$

Sukhotin AA, Abele D, Pörtner HO (2006) Ageing and metabolism of Mytilus edulis: populations from various climate regimes. J Shellfish Res 25:893-899

Sukhotin AA, Strelkov PP, Maximovich NV, Hummel H

Editorial responsibility: Lisandro Benedetti-Cecchi, Pisa, Italy
(2007) Growth and longevity of Mytilus edulis (L.) from northeast Europe. Mar Biol Res 3:155-167

Sukhotin AA, Krasnov YV, Galaktionov KV (2008) Subtidal populations of the blue mussel Mytilus edulis as key determinants of waterfowl flocks in the southeastern Barents Sea. Polar Biol 31:1357-1363

> Theisen B (1973) The growth of Mytilus edulis from Disko and Thule districts, Greenland. Ophelia 12:59-77

Thompson RJ (1984) Production, reproductive effort, reproductive value and reproductive costs in a population of the blue mussel Mytilus edulis from a sub-Arctic environment. Mar Ecol Prog Ser 16:249-257

> Versteegh EAA, Blicher ME, Mortensen J, Rysgaard S, Als TD, Wanamaker AD (2012) Oxygen isotope ratios in the shell of Mytilus edulis: archives of glacier meltwater in Greenland? Biogeosciences 9:5231-5241

$>$ Wallace J (1980) Growth rates of different populations of the edible mussel, Mytilus edulis, in north Norway. Aquaculture 19:303-311

> Wanamaker AD, Kreutz KJ, Borns HW, Introne DS and others (2007) Experimental determination of salinity, temperature, growth, and metabolic effects on shell isotope chemistry of Mytilus edulis collected from Maine and Greenland. Paleoceanography 22:PA2217

> Wassmann P, Duarte CM, Agust ÍS, Sejr MK (2011) Footprints of climate change in the Arctic marine ecosystem. Glob Change Biol 17:1235-1249

> Westerbom M, Jattu S (2006) Effects of wave exposure on the sublittoral distribution of blue mussels Mytilus edulis in a heterogeneous archipelago. Mar Ecol Prog Ser 306: 191-200

> Westerbom M, Kilpi M, Mustonen O (2002) Blue mussels, Mytilus edulis, at the edge of the range: population structure, growth and biomass along a salinity gradient in the north-eastern Baltic Sea. Mar Biol 140:991-999

> Williams RJ (1970) Freezing tolerance in Mytilus edulis. Comp Biochem Physiol 35:145-161

Submitted: October 5, 2012; Accepted: February 22, 2013 Proofs received from author(s): June 27, 2013 